\title{
Global DNA Hypomethylation and Rassf1a and c-myc Promoter Hypermethylation in Rat Kidney Cells after Bisphenol A Exposure
}

\author{
Bisfenol A Maruziyeti Sonrası Sıçan Böbrek Hücrelerinde Global DNA \\ Hipometilasyonu ve Rassf1a ile c-myc Promotör Hipermetilasyonu
}

\author{
(D) Pınar TUZCUOĞLU, (D) Sibel ÖZDEN* \\ İstanbul University Faculty of Pharmacy, Department of Pharmaceutical Toxicology, İstanbul, Turkey
}

\begin{abstract}
Objectives: Bisphenol A (BPA) is a synthetic monomer used in the production of polycarbonate and an environmental contaminant with endocrine disrupting properties. BPA release from plastic carriers is thought to cause high amounts of exposure, which result in high risk to human and environment health.

Materials and Methods: The study examined the possible changes in global DNA methylation, CpG promoter DNA methylation, and gene expressions of Rassf1a and c-myc after BPA exposure in rat kidney epithelial cells (NRK-52E).

Results: The $\mathrm{IC}_{50}$ values of BPA in NRK-52E cells were 133.42 and $101.74 \mu \mathrm{M}$ in the 3-(4,5-dimethylthiazol-2-yl)-2,5-diphenyltetrazolium bromide (MTT) and neutral red uptake tests, respectively. The cells were treated with BPA at $1 \mathrm{nM}, 10 \mathrm{nM}, 100 \mathrm{nM}, 1 \mu \mathrm{M}$, and $10 \mu \mathrm{M}$ concentrations for $24 \mathrm{~h}$ and at $100 \mathrm{nM}$ concentration for 24, 48, 72, 96 h, and 6 days. Decreased global 5-methylcytosine levels were observed after 48,72, 96 h, and 6 days at the concentration of $100 \mathrm{nM}$ BPA. Changes in CpG promoter DNA methylation were detected in the genes of Rassf1a and c-myc in BPA-treated NRK-52E cells. Expression levels of Rassf1a and c-myc changed in response to BPA at the high concentrations after $24 \mathrm{~h}$ treatment, whereas 100 $\mathrm{nM}$ exposure to BPA altered gene expression after 48, 72, and $96 \mathrm{~h}$.

Conclusion: These results indicate that changes in global and gene-specific DNA methylation may play an important role in the mechanism of BPA toxicity in kidney cells.
\end{abstract}

Key words: Bisphenol A, DNA methylation, Rassf1a, c-myc, NRK-52E cells

öz

Amaç: Bisfenol A (BPA), polikarbonat üretiminde kullanılan sentetik bir monomerdir ve çevresel bir kontaminant olup endokrin bozucu özelliklere sahiptir. BPA'nın plastik taşıyıcılardan salınması yüksek oranda maruziyete sebep olabilir, bu durum insan ve çevre sağlı̆̆ı üzerinde yüksek oranda riske sebep olabilir.

Gereç ve Yöntemler: Bu çalışmada, BPA'nın sıçan böbrek epitel hücrelerinde (NRK-52E) global DNA metilasyonu, Rassf1a ve c-myc genlerinin CpG promotör bölge DNA metilasyonu ve gen ekspresyonu üzerinde oluşturabileceği değişikliklerin araştırıldı.

Bulgular: BPA'nın IC ${ }_{50}$ değeri NRK-52E hücrelerinde 3-(4,5-dimethylthiazol-2-yl)-2,5-difenil tetrazolium bromid ve nötral kırmızı alım testi ile sırasıyla $105 \mu \mathrm{M}$ ve $88 \mu \mathrm{M}$ olarak bulundu. Hücreler $1 \mathrm{nM}, 10 \mathrm{nM}, 100 \mathrm{nM}, 1 \mu \mathrm{M}$ ve $10 \mu \mathrm{M}$ konsantrasyonlarda BPA'ya 24 saat boyunca ve $100 \mathrm{nM}$ konsantrasyonda BPA'ya 24, 48, 72, 96 saat ve 6 gün boyunca maruz bırakıldı. 48, 72, 96 saat ve 6 gün sonra 100 nM BPA konsantrasyonunda global 5-metilsitozin seviyelerinde azalma gözlendi. BPA'ya maruz bırakılmıș NRK-52E hücrelerinde Rassf1a ve c-myc genlerinin CpG promotör bölgelerinde metilasyonda değișiklikler tespit edildi. Rassf1a ve c-myc genlerinin ekspresyon seviyeleri yüksek konsantrasyonlarda 24 saat BPA maruziyet ile ve 100 nM konsantrasyonda 48, 72 ve 96 saat BPA maruziyetleri ile değișiklik gösterdi.

Sonuç: Bu sonuçlar, böbrek hücrelerinde global ve gene özgü DNA metilasyonundaki değişikliklerin BPA'nın toksisite mekanizmasında önemli bir rol oynayabileceğini göstermektedir.

Anahtar kelimeler: Bisfenol A, DNA metilasyonu, Rassf1a, c-myc, NRK-52E hücreleri

*Correspondence: E-mail: stopuz@istanbul.edu.tr, Phone: +90 2124400000 ORCID-ID: orcid.org/0000-0002-1662-2504

Received: 09.01.2019, Accepted: 21.02.2019

๑Turk J Pharm Sci, Published by Galenos Publishing House. 


\section{INTRODUCTION}

Bisphenol A [(BPA); 4,4'-dihydroxy-2,2-diphenyl propane] is an organic compound used in the production of polycarbonate. BPA is found in the composition of many products such as medical supplies, the inner coating of food and beverage packaging, the coating of electrical materials, and protective clothing. It was determined that BPA can pass into food and beverages from many materials in very small amounts. Even in normal conditions, BPA is indicated to be released from plastic carriers. Various studies have shown that BPA affects enzyme activities, metabolism, and gene activity in hormone receptors in target tissues, and deteriorates the endocrine system due to estrogenic and androgenic effects. ${ }^{2}$ It was underlined that BPA may play a role in the etiology of many diseases such as diabetes, obesity, reproductive disorders, cardiovascular disorders, congenital anomalies, renal disorders, and breast cancer. ${ }^{3}$

Many studies have been performed to evaluate the toxicity mechanisms of BPA, especially epigenetic mechanisms in various systems. ${ }^{3,4}$ Therefore, epigenetic events such as DNA methylation may play an important role in the toxicity of BPA as an endocrine disrupting chemical. $2,3,5,6$ In the present study, we aimed to examine the effects of BPA on global and gene specific DNA methylation as epigenetic mechanisms in BPA toxicity in rat kidney epithelial cells (NRK-52E) cells. The results obtained are expected to contribute to a better understanding of the key molecular mechanisms of BPA toxicity.

\section{MATERIALS AND METHODS}

\section{Chemicals}

Stock solution (100 mmol/L) of BPA ( $99 \%$ purity, Sigma-Aldrich, St Louis, MO, USA) was prepared by dissolving it in dimethyl sulfoxide [(DMSO), Wisent Bioproducts, Saint-Jean-Baptiste, $Q C$, Canada] and kept at $-20{ }^{\circ} \mathrm{C}$. Cell culture supplements were obtained from Wisent Bioproducts (Saint-Jean-Baptiste, QC, Canada) and sterile plastic materials were obtained from Greiner (Frickenhausen, Germany).

\section{Cell culture and Bisphenol A treatment}

The rat kidney proximal tubular epithelial cell line (NRK-52E) was used from the American type culture collection and cultured in Dulbecco's Modified Eagle's Medium/Ham's Nutrient Mixture F-12, supplemented with $10 \%$ fetal bovine serum and penicillin-streptomycin (100 U-100 $\mu \mathrm{g} / \mathrm{mL})$ under standard cell culture conditions $\left(37{ }^{\circ} \mathrm{C}\right.$, humidified atmosphere with $5 \% \mathrm{CO}_{2}$ ). Subculturing was performed every 2-3 days (70$80 \%$ confluence) using trypsinization. Cells were counted by a LUNA automated cell counter (Logos Biosystems, Annandale, VA, USA).

For the cytotoxicity assays, cells $\left(1 \times 10^{4}\right.$ in $200 \mu \mathrm{L}$ of medium in a 96 well plate) were exposed to BPA in the concentrations range of $31.25-1000 \mu \mathrm{M}$ and DMSO (1\%) as solvent control for $24 \mathrm{~h}$.

For the DNA methylation and gene expression analysis, cells $\left(1.5 \times 10^{6}\right.$ in $10 \mathrm{~mL}$ of medium in a $25-\mathrm{cm}^{2}$ culture flask) were exposed to BPA at the concentrations of $1 \mathrm{nM}, 10 \mathrm{nM}, 100 \mathrm{nM}$, $1 \mu \mathrm{M}$, and $10 \mu \mathrm{M}$ and DMSO (1\%) as solvent control for $24 \mathrm{~h}$, and BPA at the concentration of $100 \mathrm{nM}$ and DMSO (1\%) as control for 48 h, 72 h, 96 h, and 6 days. For all concentrations, it was tested in triplicate. Treated cells were performed for DNA isolation by High Pure PCR Template Preparation Kit (Roche Applied Science, Mannheim, Germany), and for total RNA isolation by High Pure RNA Isolation Kit (Roche Applied Science, Mannheim, Germany) according to the procedure provided by the manufacturer.

\section{Cytotoxicity}

After $24 \mathrm{~h}$ of BPA treatment, cytotoxicity tests were performed using 3-(4,5-dimethylthiazol-2-yl)-2,5-diphenyltetrazolium bromide (MTT) and neutral red uptake (NRU) tests. Briefly, in the MTT test, $20 \mu \mathrm{L}$ of MTT solution was added to each well followed by gentle mixing, and then the plate was incubated for $3 \mathrm{~h}$ at $37{ }^{\circ} \mathrm{C}, 5 \% \mathrm{CO}_{2}$. After the incubation, $100 \mathrm{\mu L}$ of DMSO $(100 \%)$ was added to each well followed by gentle mixing again. The resulting purple solution was spectrophotometrically measured at $560 \mathrm{~nm}$ with a reference wavelength of $670 \mathrm{~nm}$ using a microplate spectrophotometer system (Biotek-Epoch, Winooski, VT, USA). In the NRU test, in a 96 well plate cells were washed with $150 \mu \mathrm{L}$ of Phosphate buffered saline (PBS) solution and $100 \mu \mathrm{L}$ of neutral red vital dye was added to the cells; then the plate was incubated for $3 \mathrm{~h}$ at $37^{\circ} \mathrm{C}, 5 \% \mathrm{CO}_{2}$. The cells were washed with PBS and then $100 \mu \mathrm{L}$ of neutral red vital dye dissolution was added to each well followed by gentle mixing. Then the optical density of the plate was read at $540 \mathrm{~nm}$ using a microplate spectrophotometer system (Biotek-Epoch, Winooski, VT, USA). The cytotoxicity results were expressed as $50 \%$ of inhibitory concentration $\left(\mathrm{IC}_{50}\right)$ of the BPA that caused $50 \%$ inhibition of the enzyme activity in the cells. Based on our cytotoxicity results and previous studies in various cells, ${ }^{7-12}$ in the present study we chose BPA concentrations of $1 \mathrm{nM}, 10 \mathrm{nM}$, $100 \mathrm{nM}, 1 \mu \mathrm{M}$, and $10 \mu \mathrm{M}$ for $24 \mathrm{~h}$ treatment and a concentration of $100 \mathrm{nM}$ for $24,48,72,96 \mathrm{~h}$, and 6 day treatments for the analysis of DNA methylation and gene expression.

\section{Global DNA methylation}

Levels of global 5 -methylcytosine $(5-\mathrm{mC})$ were determined by using a 5-mC DNA ELISA kit (Zymo Research, Irvine, CA, USA) according to the instructions provided by the manufacturer. For this, $100 \mathrm{ng}$ of each DNA was denatured at $98^{\circ} \mathrm{C}$ for $5 \mathrm{~min}$ in a thermal cycler. The denatured DNA was added to the wells and incubated at $37^{\circ} \mathrm{C}$ for $1 \mathrm{~h}$. Then samples were incubated with antibody mix consisting of anti-5-mC and secondary antibody. After the washing steps, HRP developer was added to each well and absorbance was measured at $405 \mathrm{~nm}$ using a microplate spectrophotometer system (Biotek-Epoch, Winooski, VT, USA). The methylation ratio of DNA samples was calculated as a percentage using calibration standard curves by preparing mixtures of negative control ( $100 \mathrm{ng} / \mu \mathrm{L})$ and positive control (100 ng/ $\mu \mathrm{L}$ ) standards.

\section{Gene-specific DNA methylation}

Determination of DNA methylation on CpG islands in promoter regions of Rassf1a and c-myc genes was performed using 
methylation specific (MSP) PCR. In our previous study we described the study protocol in detail. ${ }^{13}$ In MSP, genomic DNA is modified by treatment with sodium bisulfite, which converts all methylated cytosines to uracil and then to thymidine during the subsequent PCR step..$^{14,15}$ Bisulfite DNA modification was performed by using an EZ DNA Methylation-Gold Kit (Zymo Research, Irvine, CA, USA) according to the manual's instructions. Methylated and unmethylated primer pairs were used to amplify each region of interest. The primer sequences are listed in Table 1. ${ }^{16,17}$ After the PCR reaction, MSP products were analyzed by agarose gel electrophoresis, stained with ethidium bromide, and visualized under ultraviolet light (Quantum ST4-Vilber Lourmat, Torcy, France).

\section{Gene expression}

First-strand cDNA synthesis was performed using 1000 ng of total RNA by using a Transcriptor First Strand cDNA Synthesis kit (Roche Applied Science, Mannheim, Germany) with a mixture of anchored-oligo (dT) and random hexamer primers according to the manual's instructions. Expression analysis of Rassf1a and c-myc genes was performed by using real-time quantitative PCR employing Light Cycler 480 Probes Master with Real Time ready Custom Single Assays (Universal ProbeLibrary Probes, Roche Applied Science, Mannheim, Germany) containing target specific primers for Rassf1a and c-myc according to our previous study. ${ }^{9}$ Cycle threshold $(\mathrm{Ct}$ ) values of Rassf1a and $c-m y c$ and the reference gene ( $\beta$-actin) were determined and evaluation of the relative expression was performed by comparative $\mathrm{Ct}$ method.

\section{Statistical analysis}

Global methylation levels and cytotoxicity results were represented as mean \pm standard deviation. Statistical analysis was performed by ANOVA (Tukey's multiple comparison procedure) using SPSS version 21.0 for Windows (IBM Analytics, New York, NY, USA). P values $<0.05$ and $<0.001$ were considered statistically significant.

\section{RESULTS AND DISCUSSION}

BPA has been frequently exposed in daily life and has been shown to be harmful in living organisms due to its endocrine disrupting properties. ${ }^{2,18-20}$ Various studies have revealed that BPA affects enzyme activity and metabolism in various tissues, causing change in the number of hormone receptors and hormone receptor gene activity in target tissues, and deteriorates the endocrine system. ${ }^{2}$ It has been revealed that BPA might induce cancer development and various studies have explained its relations with several cancer types. ${ }^{21}$ BPA can induce epigenetic changes in early life in humans and may affect several cell signaling pathways via epigenetic mechanisms. ${ }^{22}$ It has been reported in recent studies that epigenetic alterations could be useful biomarkers for the toxicity evaluation of endocrine disrupting chemicals. ${ }^{6-9,23-25}$ Therefore, in the present study, we aimed to investigate the effects of dose-dependent BPA exposure for $24 \mathrm{~h}$ and time-dependent $100 \mathrm{nM}$ concentration of BPA exposure on the alteration of global and gene specific DNA methylation and gene expression in NRK-52E cells. We chose NRK-52E cells with the characteristic properties of proximal tubule epithelial cells targeted by nephrotoxic agents to show the epigenetic effects of BPA in kidney cells.

Cell viability was determined by MTT and NRU assays in the BPA treated NRK-52E cells. The relationship between the exposure concentrations of BPA treated NRK-52E cells and \% reduction in cell viability is shown in Figure $1 . I_{50}$ values of BPA were determined as $105 \mu \mathrm{M}$ and $88 \mu \mathrm{M}$ in NRK-52E cells by the MTT and NRU tests, respectively. Decreased global DNA methylation at a concentration of $100 \mathrm{nM}$ BPA was observed in the range of $19.76 \%-25.30 \%$ after $48,72,96 \mathrm{~h}$, and 6 days (Figure 2). However, there was no change in the global DNA methylation at the concentrations of $1 \mathrm{nM}-10 \mu \mathrm{M}$ BPA for $24 \mathrm{~h}$ exposure (data not shown). Accordingly, in our previous studies, global levels of $5-\mathrm{mC} \%$ decreased after 1 and $10 \mu \mathrm{M}$ BPA treatment for $96 \mathrm{~h}$ in HepG2 cells ${ }^{8}$ and 0.1 and $1 \mu \mathrm{M}$ BPA treatments for 48 and 96 h in MCF-7 cells. ${ }^{7}$ Conversely, in another previous study, we observed no global methylation changes after $48 \mathrm{~h}$ exposure

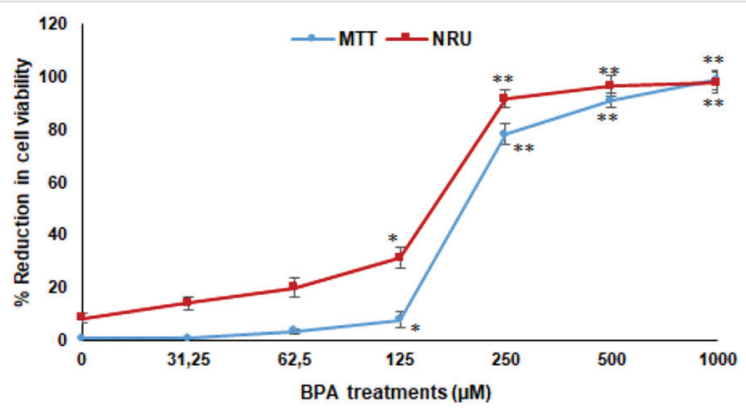

Figure 1. Effects of BPA $(0-1000 \mu \mathrm{M})$ on cytotoxicity by MTT and NR in NRK-52E cells after $24 \mathrm{~h}$ exposure. Data are presented as mean \pm SD. Statistical analysis was performed by ANOVA + dunnett post hoc test. Statistically significant changes are indicated by * $p<0.05$ and ${ }^{* *} p<0.001$

BPA: Bisphenol A, MTT: 3-(4,5-dimethylthiazol-2-yl)-2,5-diphenyltetrazolium bromide, SD: Standard deviation, NRU: Neutral red uptake
Table 1. Primer sets for MSP analysis

\begin{tabular}{|c|c|c|c|c|}
\hline Primer set & Forward primer 5' ® 3' & Reverse primer $3^{\prime} \AA^{\prime} 5^{\prime}$ & Annealing temp $\left({ }^{\circ} \mathrm{C}\right)$ & Reference \\
\hline$c-m y c-U$ & tgt ttt ttt gat ttt aga gag atg a & ctt atc cta cat ata tta atc acc aca & 55 & \\
\hline Rassf1a - U & tgt ttt ttt tgg ttt ttt ttt gtt & ata aat tca taa caa aca & 59 & \\
\hline
\end{tabular}

MSP: Methylation specific, M: Methylated, U: Unmethylated 
to BPA, whereas significant increases were seen in the global level of $5-\mathrm{mC} \%$ (1.3 fold) after $10 \mu \mathrm{M}$ of BPA for $96 \mathrm{~h}$ exposure in neuroblastoma (SHSY-5Y) cells. ${ }^{9}$ According to the results of the present study, BPA decreased global DNA methylation in rat liver, ${ }^{26}$ human fetal liver samples, ${ }^{27}$ and porcine oocyte culture at $250 \mu \mathrm{M}$ concentration. ${ }^{28}$

Rassf1 is a tumor suppressor gene that has a significant role in cancer and it is thought that its regulation was associated with CpG island promoter DNA methylation. $c-m y c$, a proto-oncogene, codes a transcription factor and controls cell proliferation. It has been shown that increases in the expression of the $c-m y c$ gene were associated with hypomethylation, which could be related to cell proliferation in liver and renal cancers. ${ }^{29-31} \mathrm{~A}$ representative profile of MSP for the $c-m y c$ gene in BPA treated NRK-52E cells is shown in Figure 3. Increases in promoter methylation were detected in Rassf1 and c-myc genes at the

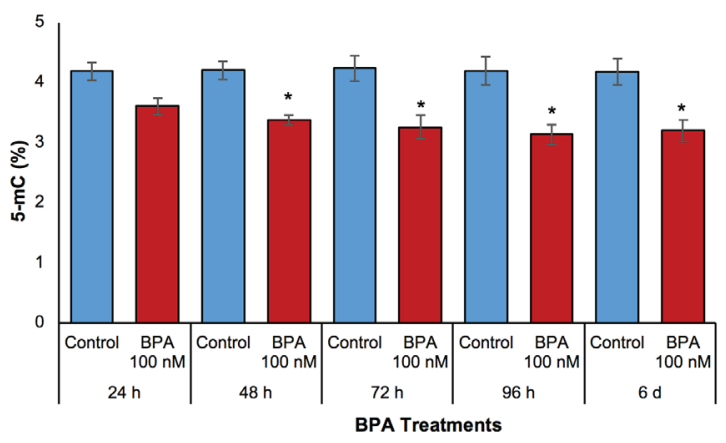

Figure 2. Effects of BPA (100 nM) in the levels of $5-\mathrm{mC} \%$ in NRK-52E cells after $24,48,72,96 \mathrm{~h}$, and 6 days exposure. Data are presented as mean \pm SD. Genomic DNA was extracted, then 5-mC\% levels were detected using the ELISA kit. Statistical analysis was performed by ANOVA + dunnett post hoc test. Statistically significant changes are indicated by * $p<0.05$

BPA: Bisphenol A, SD: Standard deviation

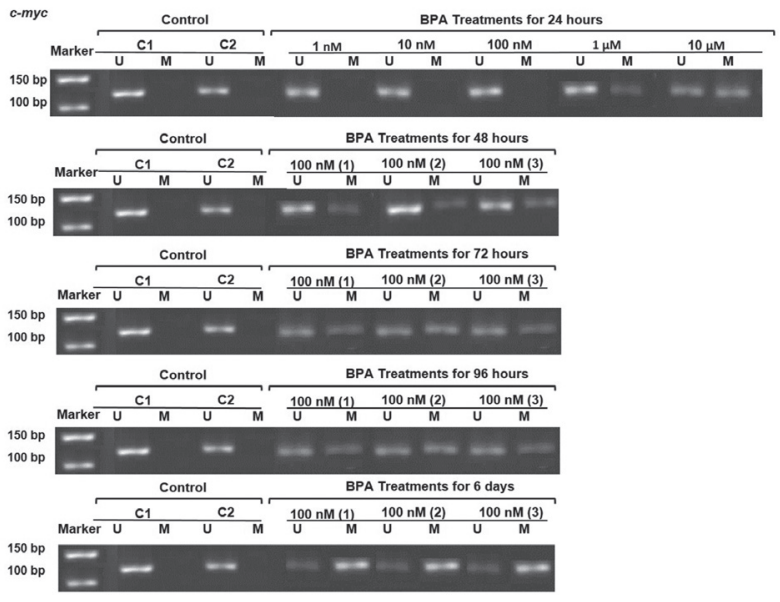

Figure 3. Effects of BPA on methylation status of c-myc in NRK-52E cells. A representative sample of NRK-52E cells treated with BPA at the concentrations of $1 \mathrm{nM}, 10 \mathrm{nM}, 100 \mathrm{nM}, 1 \mu \mathrm{M}$, and $10 \mu \mathrm{M}$ for $24 \mathrm{~h}$ and concentration of $100 \mathrm{nM}$ for $24,48,72,96 \mathrm{~h}$, and 6 days is shown. Methylation was determined by bisulfite modification of the genomic DNA and MSP using primers for the $\mathrm{U}$ or $\mathrm{M}$ promoter sequence. $\mathrm{C} 1$ and C2=DMSO (1\%) as control instead of BPA treatment

U: Unmethylated, M: Methylated, BPA: Bisphenol A, MSP: Methylation specific, DMSO: Dimethyl sulfoxide, C1: Contol 1, C2: Control 2
BPA concentrations of 1 and $10 \mu \mathrm{M}$ in NRK-52E cells over $24 \mathrm{~h}$ while no methylation was detected in control samples by using MSP following bisulfide conversion. In addition, BPA caused increases in promoter methylation of Rassf1 and c-myc genes at the concentration of $100 \mathrm{nM}$ in a time-dependent manner (48 h, 72 h, 96 h, and 6 days) in NRK-52E cells. Expression levels of Rassf1a and c-myc genes are shown in Figures 4 and 5. In response to BPA, expression of Rassf1a and c-myc was decreased at $1 \mu \mathrm{M}$ for $24 \mathrm{~h}$ (26.66\% and $37.3 \%$, respectively) and $10 \mu \mathrm{M}$ for $24 \mathrm{~h}$ (25.11\% and $22.24 \%$, respectively). Moreover, $100 \mathrm{nM}$ exposure of BPA caused decreases in expression of the Rassf1a and c-myc genes after 48, 72, and 96 h BPA treatment with regard to control samples, and there was a nonsignificant increase for 6-day BPA treatment (Figure 5). According to the results, the decrease in gene expression of Rassf1a and c-myc was correlated with DNA methylation results, which showed an increase in CpG promoter methylation of the genes. In our previous study in HepG2 cells, no change as observed in promoter methylation or gene expression of the Rassfla gene after BPA exposure. ${ }^{8}$

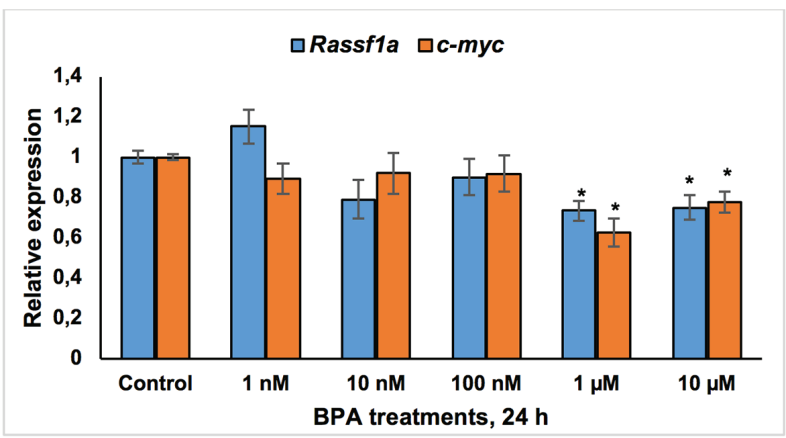

4. Effects of BPA ( $1 \mathrm{nM}, 10 \mathrm{nM}, 100 \mathrm{nM}, 1 \mu \mathrm{M}$, and $10 \mu \mathrm{M})$ on expression of Rassf1a and c-myc genes by real-time PCR in NRK-52E cells after 24 $h$ exposure. PCR reaction was done as described in the Materials and methods section. The real-time PCR results were standardized against $\beta$-actin and the relative ratios were calculated ${ }^{*} p<0.05$, BPA: Bisphenol A

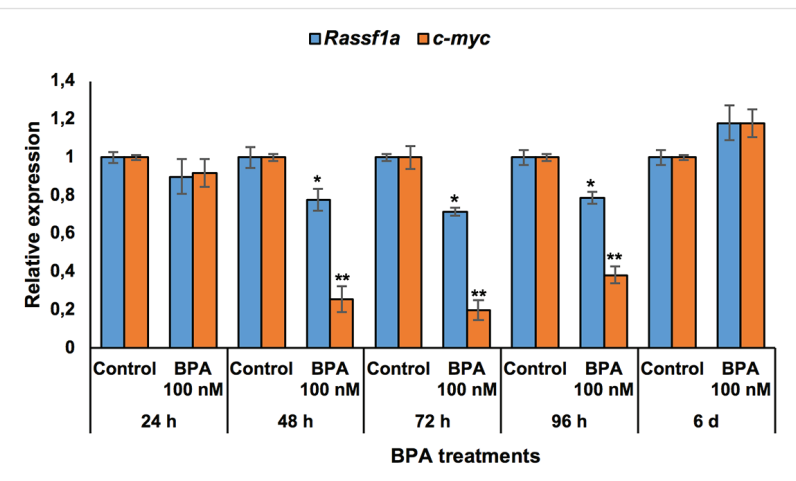

Figure 5. Effects of BPA (100 nM) on expression of Rassf1a and c-myc genes by real-time PCR in NRK-52E cells after 24, 48, 72, 96 h, and 6 days exposure. PCR reaction was done as described in the Materials and methods section. The real-time PCR results were standardized against $\beta$-actin, and the relative ratios were calculated ${ }^{*} p<0.05,{ }^{*}{ }^{*}<0.001$, BPA: Bisphenol A 


\section{CONCLUSION}

Based on the findings of the present study, BPA caused alterations in expression and methylation in the promoter region of the Rassf1a and c-myc genes associated with cancer related pathways in NRK-52E cells after 24-96 h exposure periods. It has been suggested that alterations in DNA methylation in the Rassfla and $c$-myc genes might be key regulators in the toxicity mechanisms of BPA. Further studies on the expression of chromatin modifying enzymes, DNA methylation, and global and gene-specific histone modifications after BPA exposure in cell cultures are needed to better understand alterations in epigenetic mechanisms in BPA-induced toxicity.

\section{ACKNOWLEDGEMENTS}

This study was supported partly by Scientific Research Projects Coordination Unit of İstanbul University (Project number: 40333).

Conflicts of interest: No conflict of interest was declared by the authors. The authors alone are responsible for the content and writing of this article.

\section{REFERENCES}

1. Olea N, Pulgar R, Perez P, Olea-Serrano F, Rivas A, Novillo-Fertrell A, Pedraza V, Soto AM, Sonnenschein C. Estrogenicity of resin-based composites and sealants used in dentistry. Environ. Health Perspect. 1996;104:298-305.

2. EFSA (European Food Safety Authority). Scientific opinion of the panel on food additives, flavourings, processing aids and materials in contact with food (AFC) on a request from the commission on the toxicokinetics of bisphenol A. The EFSA Journal. 2008;759:1-10.

3. Rezg R, El-Fazaa S, Gharbi N, Mornagui B. Bisphenol A and human chronic diseases: current evidences, possible mechanisms, and future perspectives. Environ Int. 2014;64:83-90.

4. Kundakovic M, Champagne F.A. Epigenetic perspective on the developmental effects of bisphenol A. Brain, Behavior, and Immunity. 2011;25:1084-1093.

5. Fleisch AF, Wright R, Baccarelli A. Environmental epigenetics: a role in endocrine disease? J Mol Endocrinolog. 2012;12-0066.

6. Greally JM, Jacobs MN. In vitro and in vivo testing methods of epigenomic endpoints for evaluating endocrine disruptors. ALTEX. 2013;30:445-471.

7. Senyildiz M, Özden S. Alteration in global DNA methylation after bisphenol A exposure in MCF-7 cells. J Fac Pharm Istanbul. 2015;45:153164.

8. Senyildiz M, Karaman EF, Baş SS, Pirinççi PA, Özden S. Alteration on global and gene-spesific DNA methylation and global histone modifications in HepG2 cells in response to BPA.J Fac Pharm Istanbul. 2016;46:97-114.

9. Senyildiz M, Karaman EF, Sancar Baș S, Arda Pirincci P, Ozden S. Effects of BPA on global DNA methylation and global histone 3 lysine modifications in SH-SY5Y cells: an epigenetic mechanism linking the regulation of chromatin modifiying genes. Toxicology in Vitro. 2017;44:313-321.
10. Nakagawa Y, Tayama S. Metabolism and cytotoxicity of bisphenol A and other bisphenols in isolated rat hepatocytes. Arch Toxicol. 2000;74:99105.

11. Terasaka H, Kadoma Y, Sakagami H, Fujisawa S. Cytotoxicity and apoptosis inducing activity of bisphenol $\mathrm{A}$ and hydroquinone in $\mathrm{HL}-60$ cells. Anticancer Res. 2005;25:2241-2247.

12. Aghajanpour-Mir SM, Zabihi E, Keyhani E, Akhavan-Niaki H, Bagherizadeh I, Biglari S, Behjati F. The genotoxic and cytotoxic effects of bisphenol-A (BPA) in MCF-7 cell line and amniocytes. Int J Mol Cell Med. 2016;5:19-29.

13. Demirel G, Alpertunga B, Ozden S. Role of fumonisin B1 on DNA methylation changes in rat kidney and liver cells. Pharm Biol. 2015;53:1302-1310.

14. Frommer M, McDonald LE, Millar DS, Collis CM, Watt F, Grigg GW, Molloy $\mathrm{PL}$, Paul CL. A genomic sequencing protocol that yields a positive display of 5-methylcytosine residues in individual DNA strands. Proc Natl Acad Sci USA. 1992;89:1827-1831.

15. Herman JG, Graff JR, Myöhänen S, Nelkin BD, Baylin SB. Methylationspecific PCR: a novel PCR assay for methylation status of $C p G$ islands. Proc Natl Acad Sci USA. 1996;93:9821-9826.

16. Li LC, Dahiya R. MethPrimer: Designing primers for methylation PCRs. Bioinformatics. 2002;18:1427-1431.

17. Niwa T, Yamashita S, Tsukamoto T, Kuramoto T, Nomoto T, Wakazono K, Fujita H, Matsushima T, Tatematsu M, Sugimura T, Ushijima T. Whole-genome analyses of loss of heterozygosity and methylation analysis of four tumor-suppressor genes in N-methyl-NO-nitro$\mathrm{N}$-nitrosoguanidine-induced rat stomach carcinomas. Cancer Sci. 2015;96:409-413.

18. LeBaron MJ, Rasoulpour RJ, Klapacz J, Ellis-Hutchings RG, Hollnagel HM, Gollapudi BB. Epigenetics and chemical safety assessment. Mutat Res. 2010;705:83-95.

19. Wolstenholme JT, Rissman EF, Connelly JJ. The role of Bisphenol A in shaping the brain, epigenome and behavior. Horm Behav. 2011;59:296305.

20. Rochester JR. Bisphenol A and human health: a review of the literature. Reprod Toxicol. 2013;42:132-155.

21. Gao H, Yang BJ, Li N, Feng LM, Shi XY, Zhao WH, Liu SJ. Bisphenol A and hormone-associated cancers: current progress and perspectives. Medicine. 2015;94:e211.

22. Singh S, Li SS. Epigenetic effects of environmental chemicals bisphenol A and phthalates. Int J Mol Sci. 2012;13:10143-10153.

23. Casati L, Sendra R, Sibilia V, Celotti F. Endocrine disrupters: the new players able to affect the epigenome. Front Cell Dev Biol. 2015;3:37.

24. Maqbool F, Mostafalou S, Bahadar H, Abdollahi M. Review of endocrine disorders associated with environmental toxicants and possible involved mechanisms. Life Sci. 2016;145:265-273.

25. Zhang X, Ho SM. Epigenetics meets endocrinology. J Mol Endocrinol. 2011:46:R11-R32.

26. Ma Y, Xia W, Wang DQ, Wan YJ, Xu B, Chen X, Li YY, Xu SQ. Hepatic DNA methylation modifications in early development of rats resulting from perinatal BPA exposure contribute to insulin resistance in adulthood. Diabetologia. 2013;56:2059-2067.

27. Faulk C, Kim JH, Jones TR, McEachin RC, Nahar MS, Dolinoy DC, Sartor MA. Bisphenol A-associated alterations in genome-wide DNA methylation and gene expression patterns reveal sequence-dependent 
and non-monotonic effects in human fetal liver. Environ Epigenet. 2015;1:dvv006.

28. Wang T, Han J, Duan X, Xiong B, Cui XS, Kim NH, Liu HL, Sun SC. The toxic effects and possible mechanisms of bisphenol A on oocyte maturation of porcine in vitro. Oncotarget. 2016;7:32554-32565.

29. Du YP, Peng JS, Sun A, Tang ZH, Ling WH, Zhu HL. Assessment of the effect of betaine on $p 16$ and c-myc DNA methylation and mRNA expression in a chemical induced rat liver cancer model. BMC Cancer. 2009;9:261.
30. Tao L, Yang S, Xie M, Kramer PM, Pereira MA. Hypomethylation and overexpression of $c$-jun and c-myc protooncogenes and increased DNA methyltransferase activity in dichloroacetic and trichloroacetic acidpromoted mouse liver tumors. Cancer Lett. 2000;158:185-193.

31. Tao L, Wang W, Li L, Kramer PK, Pereira MA. DNA hypomethylation induced by drinking water disinfection by-products in mouse and rat kidney. Toxicol Sci. 2005;87:344-352. 